\title{
84. Mogi Fossil Flora of the Province of Hizen and Its Geological Significance.
}

\author{
By Hisakatsu YABE and Seidô Endô.
}

(Comm. by H. YABE, M.I.A., June 12, 1930.)

1. The Mogi fossil flora of the province of Hizen is one of the earliest and best known of the Cenozoic floras of Japan. One day in October, 1879, Nordenskiold ${ }^{1)}$ of the Vega Expedition visited the coast of Mogi near Nagasaki and collected numerous impressions of plant leaves in a tuffite exposed at the base of the cliff of Shiroiwa. These fossils were subsequently studied by A. G. Nathorst," who found in the material about 50 species determinable with reasonable certainty. Great many of the components of the fossil flora are assignable to the plants now living in Japan, and yet there are more species (52\%, after R. Florin ${ }^{3}$ ) which are apparently now extinct from the islands. Noteworthy is the fact, among others, that the most dominant type of the fossils is Fagus ferruginea, which is now living in the Atlantic North America. According to Nathorst and Florin, there is one more Atlantic North American element, Taxodium distichum, and a Himalayan one, Rhus griffithii, in the fossil flora. In this connection, it will be added that the leaves assigned by them to Fagus ferruginea are also hardly distinguishable from those of Fagus ferruginea forma rosthornii figured by Ettingshausen ${ }^{4)}$ on the specimens collected by Arthur. v. Rosthorn from Sentsao-ping in Nanchuan district, province of Ssuchuan, China; hence this type of fossil leaves may likely point to an affinity of the Mogi flora to the recent vegetation of China rather than to that of the Atlantic North America.

2. From the very nature of the fossils now we concern, there is no doubt much uncertainty regarding to the specific determination by Nathorst and Florin, and some of them seem to need revision.

1) A. Havgaard: Nordenskiolds Voyage round Asia and Europe, a Thorough Account of the North-East Passage of the "Vega" 1878-80, (1882), p. 286.

2) A. G. Nathorst: Contributions à la Flore Fossile du Japon. K. Svenska Vetensk. Akad. Handl., XX, 2 (1883).

3) R. Florin: Zur Kenntnis der Jungtertiären Pflanzenwelt Japans. Ditto, LXI, 1 (1920).

4) C. von Ettingshausen: Die Formelemente der Europäische Tertiärbuche (Fagus feroniae Ung.). Denksch. k. Akad. Wiss. Wien, Mat.-Nat. Kl., (1894), p. 12, Pl. III, figs. 1-5; Pl. IV, figs. 2, 3. 
Yet one point unanimously indorsed by us is that the Mogi flora bears an aspect decidedly somewhat older than the Shiobara flora ${ }^{1)}$ of Shiobara, province of Shimotsuke, being more rich in the types which are either extinct from or exotic to the existing flora of the Japanese Islands. Florin, more definitely than Nathorst, claimed the Upper Pliocene age for the Mogi flora, and both agree in regarding the Shiobara flora as Pleistocene. Theoretically the precise chronological correlation of such a young flora by means of leaf-impressions is a matter of considerable difficulty or almost impossible, and the above age-determination of the two fossil floras may be accepted only as a rough approximation.

3. Far more interesting and important is the Mogi flora as an indicator of the climatic condition under which the vegetation has grown. The ancient vegetation is a mountain flora and not a coastal plain flora, notwithstanding the present geographical condition of the locality near the sea level. Nathorst pointed out that the Mogi fossil flora has grown under a condition certainly colder than the present climate of the district, and it has the constitution quite analogous to the recent vegetation of the belt of Fagus sylvatica in the sense of $\mathrm{J}$. Tanaka, which, after him, now lies in an altitude above $800 \mathrm{~m}$. in the province of Hizen.

Lately, G. Koizumi is dwelt on this problem in the connection of his phytogeographical study of the Alpine flora of Japan. Comparing the Mogi flora with the recent vegetation of Unzendake near by, he found its similarity in the mountain flora of some $1000 \mathrm{~m}$. or a little less in altitude. The view of Nathorst is therefore in the main justified and confirmed by Koizumi.

1) H. Yabe: The Volcano Shiobara and Tectonic (in Japanese). Nihon Gakujyutsu Kyôkai Hôkoku, Vol. IV (1924), p. 302-317.

2) This was almost the unique work on the forest zones of Japan then available; the Fagus sylvatica zone of Tanaka approximately coincides with the temperate zone or birch zone in a later work by S. Honda. The birch zone covers the northern half of Honshu and the western half of Hokkaido, with its southern limit approximately on $37^{\circ} 5 \mathrm{~N}$. along the coast and $35^{\circ} \mathrm{N}$. in the interior of land; the area occupied by the birch zone lies almost within the limit of $6^{\circ}$ and $13^{\circ}$ isotherms. This zone also occupies high mountains in the southern half of Honshu, Shikoku and Kyushu, its lower limit lying in average at $850 \mathrm{~m}$. above the sea level in Kyushu. J. Tanaka and T. Takashima: Investigation on the Zonal Distribution of the ForestVegetation in Japan (in Japanese), 1885. S. Honda: On the Zonal Distribution of the Forests in Japan.

3) G. Koizumi: Genetic and Floristic Phytogeography of the Alpine Flora of Japan (in Japanese). Boṭ. Mag. Tôkyô, Vol. XXXXIII, No. 393. 
No. 7.] Mogi Fossil Flora of the Province of Hizen and Its Geological.

4. The geological account of the plant beds is adequately given by J. Ohikata" as follows.

The Tertiary deposits occupying a narrow belt along the coast from Mogi, $6 \mathrm{~km}$. southeast of Nagasaki, to Kitaura comprise mostly tuffaceous rocks, as tuffaceous shale, tuff with pumice boulders and several other kinds of tuffs. All the tuffaceous rocks are in general light gray in colour and compact. The complex is overlain by a younger series of tuffaceous agglomerate and agglomerate lava; the dip of the strata is usually very low, being apparently almost horizontal. At Shiroiwa, a little north of Mogi, the strike is $\mathrm{E}-\mathrm{W}$, with southward dip; at the northern back side of the town Mogi, the dip is $8^{\circ} \mathrm{N}$. The main plant bed which occupies the lowest part of the seacliff is exposed only at low tide, and hence rather unfavourable for fossil collection.

So far as we know at present, no body has yet found any trace of marine or brackish-water organisms in this complex of tuffs and tuffites and this implies the possible fresh water origin of the deposits, despite of their present situation very close to sea coast. The good preservation of the plant leaves at least in the main plant bed of the complex is an evidence for the proximity of the original growth place of them to the final place of repose.

The geological and biological evidences cited above seem to point to the sedimentation of the Mogi beds in a water basin of a mountainland.

Once dealing with the Mogi beds in the connection of the Tertiary and later geological evolution of the land of Kyushu, one of us (Yabe)" pronounced that this complex as well as the "Tertiary" deposits in the Hitoyoshi basin and the marine deposits of the raised platform around the Bay of Kagoshima, are the superjacent complex, while the older formations altogether constitute the Fundamental complex which suffered greatly from the post-Mizuho denudation and from the succeeding block movement. The separation of the two complexes is well marked and if the time gap it implies is not much long, yet it is of the nature sufficiently important as the recorder of a pronounced earth movement.

The line of separation between the superjacent and fundamental

1) J. Ohikata: Explanatory Text to the Geological Map in 1;200,000, Sheet Nagasaki, 1913.

2) H. Yabe: Tertiary and Post-Tertiary Geological History of Kyûshû (in Japanese). Nihon Gakujutsu Kyôkai Hôkoku, Vol. I (1925), p. 177. 
complexes in Kyushu has its close analogy in that between the Narita Series and Miura Series in the Kwanto region. If the analogy should really point to contemporaneity, then certain probability seems to lie in the assumption that the Mogi beds are a complex geologically younger than the Miura Series; on the other hand the Mogi flora is somewhat older than the Shiobara flora, as stated above.

Our study of the Tertiary and post-Tertiary history of the Shiobara volcanic district has shown that the Shiobara group comprises volcanic sediments deposited in a water basin, temporally existed between the fault scarp of a northerly lying higher landblock and volcanic ejecta coming from south. The lake was approximately $700 \mathrm{~m}$. high above the sea-level of that time." The Shiobara group is a terrestrial equivalent of the marine Narita Series of the Kwanto region, which comprises the sediments of the geological epoch when the Japanese Islands were in position more submerged than now.

The geological age of the Mogi flora was heretofore treated only from the palaeophytological standpoint, but at present the question can no longer be dealt with independent from other geological data. It is now possible to entertain on all the circumstances set forth above an opinion that the Mogi flora can be explained as a mountain flora just of the latest continental stage of the Japanese Islands, ${ }^{2)}$ and grown in an altitude of approximately $720 \pm \mathrm{m}$. above the sea level of that time, without any other additional assumption.

In the latest continental stage, the climate of the western part of Kyushu was certainly less equable, not only by its higher altitude than now, but also by lacking ameliorating climatic effect of warm ocean current on that side owing to its broad land connection to the Asiatic continent. The meteological condition then prevailed over Kyushu was much different from the present state and we can expect the isotherms shifted considerably southwestwards and the lower limit of each forest zone on mountains shifted downwards. Then the elevation of land amounting to $1000 \pm \mathrm{m}$. is apparently by no means requested for the position of the growth place of the ancient forest which supplied the plant leaves to the Mogi beds.

1) The highest shore line of the fossil lake is about $800 \mathrm{~m}$. above the present sea-level and the sea-level of that time is now thought to be some $100 \mathrm{~m}$. higher than that of the present day from the study of the terraces of the Kwantô tectonic basin by Messrs. Aoki and Tayama.

2) H. Yabe: The Latest Land Connection of the Japanese Islands to the Asiatic Continent. Proc. 5 (1929), 167-169. H. Yabe: Geological Age of the Latest Continental Stage of the Japanese Islands. Ibid., Vol. V, No. 9 (1929), p. 430-433. 